\title{
Impression management within the recruitment interview: Narratives of employees at a South African higher education institution
}

\begin{tabular}{|c|c|}
\hline \multicolumn{2}{|c|}{$\begin{array}{l}\text { Vuyelwa Dondolo }{ }^{1} \bullet \\
\text { Willie T. Chinyamurindi }\end{array}$} \\
\hline \multicolumn{2}{|c|}{$\begin{array}{l}\text { Affiliations: } \\
{ }^{1} \text { Teaching and Learning } \\
\text { Centre, University of Fort } \\
\text { Hare, South Africa }\end{array}$} \\
\hline \multicolumn{2}{|c|}{$\begin{array}{l}{ }^{2} \text { Department of Business } \\
\text { Management, University of } \\
\text { Fort Hare, South Africa }\end{array}$} \\
\hline \multicolumn{2}{|c|}{$\begin{array}{l}\text { Corresponding author: } \\
\text { Willie Chinyamurindi, } \\
\text { chinyaz@gmail.com }\end{array}$} \\
\hline \multicolumn{2}{|c|}{$\begin{array}{l}\text { Dates: } \\
\text { Received: } 05 \text { Apr. } 2018 \\
\text { Accepted: } 22 \text { June } 2018 \\
\text { Published: } 26 \text { Sept. } 2018\end{array}$} \\
\hline \multicolumn{2}{|c|}{$\begin{array}{l}\text { How to cite this article: } \\
\text { Dondolo, V., \& } \\
\text { Chinyamurindi, W.T. (2018). } \\
\text { Impression management } \\
\text { within the recruitment } \\
\text { interview: Narratives of } \\
\text { employees at a South African } \\
\text { higher education institution. } \\
\text { SA Journal of Industrial } \\
\text { Psychology/SA Tydskrif vir } \\
\text { Bedryfsielkunde, 44(0), } \\
\text { a1547. https://doi.org/ } \\
\text { 10.4102/sajip.v44i0.1547 }\end{array}$} \\
\hline \multicolumn{2}{|c|}{$\begin{array}{l}\text { Copyright: } \\
\text { ( } 2018 \text {. The Authors. } \\
\text { Licensee: AOSIS. This v } \\
\text { is licensed under the } \\
\text { Creative Commons } \\
\text { Attribution License. }\end{array}$} \\
\hline \multicolumn{2}{|l|}{ Read online: } \\
\hline 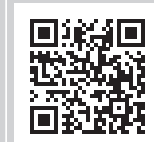 & $\begin{array}{l}\text { Scan this QR } \\
\text { code with your } \\
\text { smart phone or } \\
\text { mobile device } \\
\text { to read online. }\end{array}$ \\
\hline
\end{tabular}

Orientation: Job interviews remain a popular platform on which organisations source talent. Interviewees seek to make an impression in interviews to influence the decision to be hired.

Research purpose: The study explores why and how impression management manifests within the recruitment interview setting.

Motivation for the study: Calls exist within the local and international literature for studies that explore the concept of impression management further as a basis to improve activities such as recruitment and selection.

Research approach, design/method: An interpretivist research paradigm using the qualitative approach and the exploratory research design was utilised. In-depth interviews with 20 employees at a South African higher education institution were conducted. Narrative analysis formed the basis of the data analysis by adopting the three levels of the meaning-making approach used in previous studies.

Main findings: Two major narratives emerged. Firstly, when exploring why impression management occurs in the recruitment interview, the strategising behaviour was identified. Secondly, when exploring how impression management occurs in the recruitment interview, the switching behaviour was identified.

Practical/managerial implications: The study provides information that organisational strategists and recruiters can use to enhance not only the recruitment process but also the decisions informed by such processes.

Contribution/value-add: This study contributes to the growing body of knowledge in an area of study that has received scant empirical focus locally and internationally. This can be a catalyst for future research on impression management.

\section{Introduction}

The ability to make decisions is an important organisational capability (Chinyamurindi, 2016a; Fisher, Schoenfeldt, \& Shaw, 2006) that can provide direction for the organisation (Louw, 2012). This can form a basis for a competitive advantage (Louw, 2013). Furthermore, paying attention to the decision-making capability has ramifications for workplace output (Tsai \& Huang, 2014). The requirement is to provide processes within organisations that support this (Grobler, Warnich, Carrell, Elbert, \& Hatfield, 2011). An important decision that needs to be made within organisations is concerned with the recruitment and selection of employees (Chinyamurindi \& Louw, 2010; Chiwara, Chinyamurindi \& Mjoli, 2017; Louw, 2012).

Recruitment decisions concern prioritising that a workforce will be able to meet the current and future needs of the organisation (Aamodt, 2013). By such a prioritisation, organisations are able to place the right people in the right positions, thus enhancing organisational development (Grobler et al., 2011). However, when making such decisions, impression management as a behaviour can occur on both the interviewer's and the interviewee's sides (Abbott, Goosen, \& Coetzee, 2013; Ployhart, Schneider, \& Schmitt, 2006). Impression management has the potential to affect not only the quality of decisions but also outcomes from human resources management (HRM) processes such as recruitment and selection.

Impression management has been defined to be an effort, whether conscious or unconscious, to control the image that is perceived by others of the self (Mtshelwane, Nel \& Brink, 2016). 
Impression management concerns how individuals portray themselves 'to be perceived favourably by others' (Hooghiemstra, 2000, p. 60). The concept of impression management follows in its early conceptualisation a dramaturgical metaphor as a performance of the self in relation to an audience (Goffman, 1959).

The literature seems to position impression management as a concept studied from various disciplines including marketing (Fisk \& Grove, 1996), accounting (Godfrey, Mather, \& Ramsay 2003), social psychology (Allport, 1954), economics (Demers \& Vega, 2010) and tourism services (Yan \& Ho, 2017). Impression management can also be evident within an HRM context, especially concerning recruitment decisions, for three reasons. Firstly, the recruitment interview relies on prospective candidates sharing their stories and experiences (Galletta \& Cross, 2013). This process by nature may potentially result in the prospective candidates exaggerating their stories and experiences to sway a decision in their favour. Secondly, recruitment interviews seek to elicit those stories and experiences that are retrospective (O'Neil \& Horne, 2012). Such a focus, as inevitable as it may be, can be a strength and a weakness. Chinyamurindi (2016b) lauds interviews as offering a platform on which the past, present and future can be understood. However, the concern is that there are few or no processes to validate interviewees' accounts. This potentially gives rise to impression management as a concept that has been researched and debated internationally (Howle, Jackson, Conroy, \& Dimmock, 2015; Kacmar \& Carlson, 1999; Patel, Gali, Patel, \& Parmer, 2011; Schlenker, 1980; Sung, Lin, Connor, \& Chan, 2017) and recently within a South African Industrial Organisational Psychology (IOP) context (Mtshelwane et al., 2016). This study seeks to expand understanding into impression management within an IOP discipline by specifically focusing on the recruitment interview setting.

Central to impression management, as argued by Ward and Ravlin (2016, p. 3), is 'status enhancement', be it in a context of real or imagined audiences (Abbott et al., 2013). Impression management is viewed as a form of self-representation in view of the construction of social reality (Leary \& Kowalski, 1990). This can often result in the creation of a desirable image of the self, whether truthful or deceitful, to gain favour from an audience (Goffman, 1959; Kolb, 2017). Impression management thus emerges as a possible performative behaviour (Goffman, 1959) with either positive or negative outcomes (Mtshelwane et al., 2016). Within the context of work, impression management is really done to secure a positive outcome for the individual (Dimba \& Rugimbana, 2013).

\section{Research objectives}

This study aims to explore why and how impression management manifests within the recruitment interview setting, using a sample of academics at a South African higher education institution. This aim is actuated and influenced by three main observations from the extant literature. Firstly, there is a growing body of international literature calling for focus on understanding impression management within organisational studies (Howle et al., 2014; Kacmar \& Carlson, 1999; Patel et al., 2011; Schlenker, 1980; Sung et al., 2017). Secondly, calls exist with the South African IOP context to be expansive in understanding the concept of impression management (Mtshelwane et al., 2016). Finally, although a number of studies have been conducted with a specific focus on recruitment (Chinyamurindi \& Louw, 2010; Kerr-Phillips \& Thomas, 2009; Louw, 2013), the link between impression management and the recruitment process remains an area that deserves further exploration in South Africa (Mtshelwane et al., 2016). All these are apparent gaps that this research seeks to fill. The research question that guided the study was the following: Why and how does impression management manifest within the recruitment interview setting amongst a sample of academics at an institution of higher learning in South Africa?

\section{Literature review}

To understand the concept of impression management, the study utilised the interpersonal deception theory (IDT) (Buller \& Burgoon, 1994) and the attribution theory (AT). The IDT proposes that individuals tend to be deceptive in their interaction with others to be liked or favoured (Buller \& Burgoon, 1994; Seiter \& Gass, 2004). It is from this desire to be liked that impression management exists. The AT posits that individuals make attributions a basis of interaction and that may often result in bias (Spitzberg \& Manusov, 2014). Interviews by nature can provide an opportunity through which this bias can happen (Sung et al., 2017), as they form a basis through which interviewees can express themselves to interview panels (Caruth, Caruth \& Pane, 2009). Thus, the AT seeks to provide a plausible explanation of events from the lens of the individual (Merkl-Davies, Brennan \& Mcleay, 2011).

\section{Impression management behaviours: The why and how?}

The empirical literature identifies a number of impression management behaviours. These behaviours can be deliberate with the aim to sway towards a particular desired point (Mtshwelane et al., 2016). This usually can mean an individual holds power over his or her audience through his or her selfrepresentation (Diekmann, Blickle, Hafner, \& Peters, 2015; Jones \& Pittman, 1982). These behaviours can consist of (1) self-promotion, (2) ingratiation, (3) intimidation, (4) supplication and (5) exemplification (Jones \& Pittman, 1982). Other researchers (Zhao \& Liden, 2011) have found self-promotion to be prevalent when recruiting students with success. Conversely, not all impression management behaviours result in positive outcomes (Johnson, Griffith, \& Buckley, 2016). This often happens when some form of rapport is established between the interviewer and the interviewee to question some of these self-representations (Leung, Parker, \& Courtis, 2015). 
Impression management is also noted as a behaviour that even organisations can be engaged in to sway individuals to see the good of their brand (Benson, Brau, Cicon \& Ferris, 2015). It can also be manifested through company reporting to effect a positive public perception of a company (Aerts \& Cormier, 2009). Within an interview setting, all these efforts by individuals and organisations have been classified as a front to portray a false image (Tsai \& Huang, 2014). In most cases, this can be seen as deceitfulness (Stiff, 1996) with no assurance of guaranteed performance when the decision to recruit is made (Yu \& Cable, 2014).

Some people position impression management not just as a verbal discourse but even through items of clothing as a way to make an impression (Bligh, 1998). As with the verbal tactics of impression management, the aim is to depict a desirable side to impress an interview panel (Wilhelmy, Kleinmann, Konig, Melchers \& Truxillo, 2015). In a study amongst call centre agents in India, Raghuram (2013) found impression management to manifest through using foreign accents, using Western names and those scripts that convey physical proximity to customers. Therefore, interviewees identify an impression management technique called foreshadowing where only a limited amount of information can be disclosed so as not to be put at a disadvantage (Busenbark, Lange, \& Certo 2017). In essence, impression management especially in service professions, is for the purpose of swaying decisions, be they verbal or non-verbal, for image building or selfpresentation (Yan \& Ho, 2017).

\section{Research design}

This section explores the research design and consists of the research approach, strategy and method.

\section{Research approach}

An interpretivist paradigm hinging on the qualitative approach was adopted for this study as used in previous South African studies on impression management (Mtshelwane et al., 2016) and organisational narrative studies (Chinyamurindi, 2012, 2016a). Such a paradigm and approach allowed the researchers to gain an in-depth knowledge of phenomena, including the lived experiences of the participants (Creswell, 2009, 2014).

\section{Research method \\ Population and sampling techniques}

The study used a purposive convenience sampling approach. According to this approach, participants must have gone through a recruitment interview as a passage of entry into the university. Furthermore, all participants had to be full-time employees with the participating university. From this, a total of 20 participants were recruited, who shared their experiences of impression management. Table 1 presents the characteristics of the participants.
TABLE 1: Characteristics of the participants.

\begin{tabular}{|c|c|c|c|c|}
\hline Pseudonyms & Gender & Age range & Focus area & $\begin{array}{l}\text { Institutional work } \\
\text { experience }\end{array}$ \\
\hline 1 & Male & DNS & $M \& C$ & 9 \\
\hline 2 & Female & $63-68$ & $E \& A D$ & 8 \\
\hline 3 & Female & $43-48$ & $E \& A D$ & 17 \\
\hline 4 & Male & $28-33$ & $E \& A D$ & DNS \\
\hline 5 & Female & $38-43$ & $E \& A D$ & DNS \\
\hline 6 & Female & $43-48$ & $E \& A D$ & 22 \\
\hline 7 & Female & $58-63$ & SS \& H & 40 \\
\hline 8 & Male & $33-38$ & $M \& C$ & 8 \\
\hline 9 & Male & $28-33$ & $M \& C$ & 4 \\
\hline 10 & Male & $28-33$ & HS & 4 \\
\hline 11 & Male & $43-48$ & SS \& H & 19 \\
\hline 12 & Male & $28-33$ & $M \& C$ & 9 \\
\hline 13 & Male & $63-68$ & $M \& C$ & 20 \\
\hline 14 & Male & $28-33$ & $M \& C$ & 5 \\
\hline 15 & Female & $33-38$ & $M \& C$ & 8 \\
\hline 16 & Female & DNS & $E \& A D$ & DNS \\
\hline 17 & Male & $28-33$ & $M \& C$ & 5 \\
\hline 18 & Male & $28-33$ & $M \& C$ & 4 \\
\hline 19 & Male & $38-43$ & HS & 18 \\
\hline 20 & Female & $43-48$ & $M \& C$ & 26 \\
\hline
\end{tabular}

$M$ \& $C$, management and commerce; HS, health sciences; SS \& $H$, social sciences and humanities; E \& AD, education and academic development; DNS, did not specify.

\section{Data collection and measuring instrument}

Data were collected through in-depth interviews relying on the storytelling approach used in previous South African organisational narrative research (Chinyamurindi, 2012, 2016a, 2016b; Harry, Dodd, \& Chinyamurindi, 2017). An interview guide was prepared and each question posed to the participants was intended to elicit stories and experiences. This was deemed a useful technique, not only to keep the participants engaged, but also to act as a way of arriving at the narratives that form a result of the data analysis process. All interviews were recorded with the participants' permission and transcribed verbatim within $24 \mathrm{~h}$ of the interview taking place. Furthermore, notes were taken during the interviews and were used together with the audio recordings and subsequently the transcriptions for the purpose of data analysis.

\section{Data analysis}

Initial data analysis consisted of using a means of structural analysis (Labov, 1972). This technique of structural analysis consisted of a process of summarising the transcribed data, based on the experiences shared by the participants (Klapproth, 2004) into segments identified by Labov (1972). All these steps of initial analysis were deemed useful in preparing the data for the subsequent narrative analysis. To achieve the narrative analysis, an approach known as the three levels of meaning-making (McCormack, 2000) was used to help give meaning to the data. This approach has been used in previous research within a South African IOP context working with narrative data (Chinyamurindi, 2012, 2016a, 2016b; Harry et al., 2017). Table 2 summarises the three levels of meaning-making as used in previous research. 
TABLE 2: Data analysis procedure.

\begin{tabular}{ll}
\hline Level of meaning & Description \\
\hline Level 1 & $\begin{array}{l}\text { Each interview is written as a brief vignette. Then, each vignette } \\
\text { is developed into a longer narrative about each participant. }\end{array}$ \\
Level 2 & $\begin{array}{l}\text { Narrative themes are conveyed by participants and their } \\
\text { experience of career development. Then, preliminary themes } \\
\text { are compared between participants. }\end{array}$ \\
Level 3 & $\begin{array}{l}\text { An analysis of the themes from cross-case comparison begins } \\
\text { and illustrating quotes and stories are used. }\end{array}$ \\
\hline
\end{tabular}

Note: This process was also applied extensively in previous empirical work using narrative in South Africa.

\section{Strategies employed to ensure data quality}

In any study, it is essential to ensure reliability and validity; in the case of this study, strategies were used in ensuring data quality. Firstly, the research team had to clarify the essence of the research, which comprised the experiences of impression management amongst employees at a rural institution in the Eastern Cape province during the recruitment process. Secondly, the protection of the participants was of paramount importance. Pseudonyms were used from Participants 1-20 in order to conceal their identities and ensure anonymity. The third strategy was the use of a tape recorder to ensure that the capturing of the essence and articulation of the participants' stories was accurate (Chinyamurindi, 2012). Then, the research team prepared the data collected. This consisted of assembling notes from note taking, transcripts and any other material that was used to collect the data. After transcribing from the tape recorder and side notes, the research team sent copies of the transcribed interviews to the participants in order to validate the information captured (Creswell, 2009).

\section{Ethical consideration}

Firstly, ethical clearance was applied for and granted by the participating institution to conduct this study. Secondly, the research team did not seek to harm any participants through the study. Informed consent forms were issued and discussed before the commencement of the interviews. The study was voluntary and the participants were informed that they could withdraw from the study if at any stage they felt uncomfortable. Finally, confidentiality was emphasised to the participants.

\section{Findings}

From the data collected, two major narratives emerged. Firstly, when exploring why impression management occurs in the recruitment interview, the strategising behaviour was identified. Secondly, when exploring how impression management occurs in the recruitment interview, the switching behaviour was identified. These findings are discussed in more detail next.

\section{Why impression management? The motif of strategising}

The participants expressed the motif of impression management to be rooted in strategising. This simply meant any individual effort to better position themselves ahead of other prospective employees and to make a favourable impression on the interviewing panel. One participant acknowledged that his surroundings prompted him to adjust his responses in order to fit the targeted audience. The participant shared:

'The trick here is to get the panel on your side by making sure that you play to the gallery. If I go for an interview, say in Durban, I am careful to create an impression that suits that condition. If I have an all-female dominated panel, I channel responses to fit this audience and so I can be seen in a positive light.' (Participant 16 , Female, Academic)

Another participant equalled strategising to a form of public relations:

'Interviews success depends on public relations and in the end explains what we do in interviews. This is about managing the impression that you actually give out to people. At times it may mean promoting a certain part of yourself more than other parts to satisfy the panel.' (Participant 7, Female, Academic)

To some participants, impression management manifested through strategising that comprised trying to get as much information about the panel before the interview. Based on the information gathered, the idea was to prepare plausible responses to impress the panel. One participant narrated this experience:

'The trick is to gather as much information as possible about your panel. This is a university community and you are certain with a guess who possible can be member of the panel. Then try and work whatever responses to questions to fit the wellknown views of the panel members.' (Participant 10, Male, Academic)

Linked to this, some participants stated that impression management manifests through strategising to not only consist of giving structured verbal answers with the view to sway a panel but also the role of non-verbal communication. One participant narrated this experience of strategising with an attribution to the self-consciousness:

'I think it's something you learn and do it self-consciously. For example, you learn to control your language, and you watch the language that you use in every situation that you're in. For me you know more about the panel and the body language favourable to them. So you know what and what not to say.' (Participant 7, Female, Academic)

Another participant supported this statement by admitting that impression management sometimes comes naturally:

'I would say mostly subconsciously it comes up in an interview where you want to put your best foot forward where you kind of exaggerate your strengths and then you diminish your weaknesses or turn your weaknesses into potential strengths or die-hard weaknesses where you come out as the hero.' (Participant 10, Male, Academic)

One participant suggested that the reason why he used impression management was because he had certain expectations from the interview. These expectations allowed him to prepare accordingly, as shown in the following extract: 
TABLE 3: Data coding process for impression management manifestation during the recruitment process.

\begin{tabular}{|c|c|c|c|}
\hline Initial codes & Question answered & Emerging narrative & Illustrating quotes \\
\hline $\begin{array}{l}\text { Public relations, promote a certain } \\
\text { understanding of yourself, control } \\
\text { your language, emotional intelligence, } \\
\text { cross-culture impression management, } \\
\text { present yourself }\end{array}$ & $\begin{array}{l}\text { Why of impression } \\
\text { management? }\end{array}$ & Strategic play & $\begin{array}{l}\text { - 'First impressions last the most and so I positioned myself as }[a] \text { person who would } \\
\text { want that impression to leave a lasting imprint. I do my research about the panel and } \\
\text { I apply this in the interview.' (Participant 7, Female, Academic) } \\
\text { - 'I went in thinking what they are going to ask or what do they want to know about, } \\
\text { because it was a very short interview. So I oversell myself to achieve this.' (Participant } \\
\text { 9, Male, Academic) } \\
\text { - 'Come what may - I need them to see me as a possible candidate. I will do anything } \\
\text { that this happens.' (Participant 16, Female, Academic) }\end{array}$ \\
\hline $\begin{array}{l}\text { False confidence, deception, diverting } \\
\text { attention, exaggerate your strengths, } \\
\text { good weaknesses }\end{array}$ & $\begin{array}{l}\text { How of impression } \\
\text { management? }\end{array}$ & Switching attention & $\begin{array}{l}\text { - 'Make the panel you know your stuff even when you don't. Use any diversionary } \\
\text { tactic at all cost.' (Participant 2, female, Academic) } \\
\text { - 'They say put your best foot forward. If this does not work, then create an impression } \\
\text { that you have put the best foot forward.' (Participant 10, Male, Academic) } \\
\text { - 'I usually apply a false confidence I mean no matter... if I am scared, there [is] no } \\
\text { room to look scared. Alternatively, I make the panel focus on something about me } \\
\text { to hide the fear.' (Participant } 1 \text {, Male, Academic) }\end{array}$ \\
\hline
\end{tabular}

'I expected that I will be asked about my discipline and that's what I prepared and I had to read as much as possible about the subject.' (Participant 13, Male, Academic)

There was firm acknowledgement from the different participants as to why they use or have used impression management during job interviews. Different circumstances have driven these participants to acknowledge their surroundings and what they would like to achieve in the end to be motivation for the use of impression management. Ultimately, the motif of strategising explained why impression management was used. The next finding illustrates how impression management manifests.

\section{How does impression management manifest? The art of switching attention}

There are several methods and tactics that one can use to appear favourable to the interviewing panel. The participants gave their detailed experiences of using impression management in the past. Switching attention was a route that the participants used to gain favour with the interviewing panel. Switching attention entailed distracting interview panel members from recognising a true personality. One participant stated that he had used false confidence in one of his interviews to switch attention:

'I did not know the answer and decided to use false confidence. I was scared but there was no room to look scared. I acted like I knew what I was doing.' (Participant 1, Male, Academic)

Participant 2 supported Participant 1's suggestion that false confidence is a useful tool during a job interview:

'I have learnt that in an interview you must focus the panel towards strengths and not weaknesses. So you must come across confident and be a smooth talker. In the end this is what the panel needs to see. So I drive a panel towards something that I may not be.' (Participant 2, Female, Academic)

Another participant recalled one of his past job interviews during which he was asked a certain question that seemed difficult or even unanswerable:

'For instance, I was asked the difference between interdisciplinary and transdisciplinary and I had never prepared for that question.'(Participant 12, Male, Academic)

At this stage, the participant was feeling anxious because of this unexpected question from the panel. However, through switching attention, the participant managed to articulate a plausible answer:

'I started talking about a trans-Atlantic flight I took. This at least changed the focus of the panel to show them that I am welltravelled. I then positioned an answer that was not too convincing. Trans means different context and Inter means between two subject areas. The answer was not convincing but at least I conveyed a subtle message about me.' (Participant 3, Female, Academic)

Table 3 presents a summary of the two narrative findings and some illustrating quotes.

\section{Discussion}

The objective of this study was to explore why and how impression management manifests within the recruitment interview setting. The context in which this study was located was within a higher education setting. The findings of the study extend emerging literature within an IOP context where impression management is being studied (Mtshelwane et al., 2016). In essence, impression management in this study, and from the lens of the individual, is being framed as a tool allowing for a decision to work in their favour and advantage (Hooghiemstra, 2000). Thus, impression management can also be considered to be an individual capability in the enactment of a desired outcome. This study heightens focus on how this happens from the interviewee's side (Abbott et al., 2013; Ployhart et al., 2006). The two findings of the study appear to support emerging work around impression management in South Africa (Mtshelwane et al., 2016), namely that the phenomena can be both conscious and unconscious. The two findings of this research (the why and how of impression management) can be considered behaviours that seek not only to enhance status (Ward \& Ravlin, 2016), but also to act as a way of self-presentation to understand how reality is understood and experienced (Abbott et al., 2013; Leary \& Kowalski, 1990).

This study uniquely locates this finding within a recruitment interview setting of a higher education institution. Based on previous studies, this could show the enduring nature of impression management as a concept across disciplines. Thus, this work extends from previous work in various disciplines outside IOP (Allport, 1954; Demers \& Vega, 2010; Fisk \& Grove, 1996; Godfrey et al., 2003; Yan \& Ho, 2017) and 
within IOP, especially in South Africa (Mtshelwane et al., 2016). As organisations recruit the best employee in order to gain a competitive edge over other organisations (Louw, 2013), one way of doing so is going through the rigorous process of recruitment and selection (Chinyamurindi \& Louw, 2010). These findings provide a clear indication that interviewees would use any tactics to get employment or be seen as desirable.

The two findings of this study also heighten focus, not only on the agentic power of the interviewee, but also, as positioned in the theoretical literature, the dramaturgical metaphor of individual performance of the self in relation to an audience (Goffman, 1959). In essence, the interview set-up by virtue of being a platform to share stories and experiences (Galletta \& Cross, 2013), and also its retrospective framing of reality (O'Neil \& Horne, 2012), can make impression management an inevitable phenomenon.

\section{Practical implications}

Some practical implications based on the research can be suggested. Considering the argued value of activities such as recruitment (Louw, 2012, 2013; Chinyamurindi \& Louw, 2010), recruitment panels can use the findings of this research to be better informed on those cues with the intent of impression management that may lead to undeserving candidates being appointed. To this end, the findings of this study provide useful knowledge to assist in improving the quality of decision-making (Tsai \& Huang, 2014). Subsequently, this assists management action to ensure that the right people are appointed in the right positions for the purpose of achieving optimal returns. Furthermore, given potential interviewees taking multiple actions through information acquisition of even panel members, there is a need for a total revamp of recruitment systems in organisations. This can potentially assist to eliminate the possibility of predictable questions or even the members of a panel. There is a need in this regard to be constantly redefining the recruitment process through its questions and panel members, given the tactic of impression management. The findings of this study will be sent to an HR department with suggestions for decision-makers and recruiters to be aware of false representations given by interviewees and to research more feasible strategies to improve recruitment interviews.

\section{Limitations and recommendations of the study}

Some notable limitations exist with this work. Firstly, considering the number of institutions in South Africa, this research was conducted in one university located in the Eastern Cape province. The findings are in no way claiming generalisability to the entire university population in South Africa. Secondly, taking into account that this was a qualitative study, shortcomings around access to a representative sample are noted. Thirdly, another limitation is that the sample of participants comes from predominantly one discipline.

Future research can improve on this research. Firstly, continual use of a narrative and storytelling approach can be used in conjunction with other research techniques such as a visual methodology. This strategy may assist in eliciting richer stories away from the vague descriptions which my lack experiences. This is an effort that can improve the richness of textual data (Labov, 1972). Secondly, future research could focus on understanding the aspects of impression management (the detection of this) from the angle of the interviewer. Thirdly, given the absence of measuring instruments, specific to aspects of impression management, especially within a South African context, future research could attempt to develop such instruments. Qualitative research like this study can potentially set the scene for the development of such instruments.

\section{Conclusion}

It is important to understand individual behaviour, especially concerning aspects of the decisions that they make. This may include those behaviours classified as self-representations made to sway a decision in favour of the individual. Ultimately, studies such as these assist in unearthing the often complex and innate aspects of behaviour. The field of IOP can benefit from such efforts.

\section{Acknowledgements}

The authors acknowledge and appreciate all the participants for taking part in the study.

\section{Competing interests}

The authors declare that they have no financial or personal relationships that may have inappropriately influenced them in writing this article.

\section{Authors' contributions}

V.D. collected and analysed the data. She was responsible for writing the first two drafts of this paper. W.T.C. supervised V.D. for her Master's studies. W.T.C. also oversaw the data analysis and writing of the article.

\section{References}

Aamodt, M. (2013). Industrial/organisational psychology: An applied approach (7th edn.). Boston, MA: Cengage Learning. https://doi.org/10.4102/sajhrm. v11i1.408

Abbott, P., Goosen, X., \& Coetzee, J. (2013). The human resource function contribution to human development in South Africa. South African Journal of Human Resource Management, 11(1), 1-14.

Aerts, W., \& Cormier, D. (2009). Media legitimacy and corporate environmental communication. Accounting, Organizations and Society, 34(1), 1-27. https://doi. org/10.1016/j.aos.2008.02.005

Allport, G. W. (1954). The nature of prejudice. Cambridge: Addison Wesley.

Benson, D. F., Brau, J. C., Cicon, J., \& Ferris, S. P. (2015). Strategically camouflaged corporate governance in IPOs: Entrepreneurial masking and impression management. Journal of Business Venturing, 30(5), 839-864. https://doi. org/10.1016/j.jbusvent.2015.03.001 
Bligh, D. A. (1998). What's the use of lecturers? (5th edn.). Exeter: Intellect.

Buller, D. B., \& Burgoon, J. K. (1994). Deception: Strategic and non-strategic communication. In J. A. Daly \& J. M. Wiemann (Eds.), Strategic interpersonal communication (pp. 191-223). Hillsdale, NJ: Erlbaum.

Busenbark, J. R., Lange, D., \& Certo, S. T. (2017). Foreshadowing as impression management: Illuminating the path for security analysts. Strategic Management Journal, 38(12), 2486-2507. https://doi.org/10.1002/smj.2659

Caruth, D. L., Caruth, G. D., \& Pane, S. S. (2009). Staffing the contemporary organization: A guide to planning, recruiting, and selecting for human resource professionals (3rd edn.). Westport, CT: Praeger Publishers.

Chinyamurindi, W. T. (2012). An investigation of career change using a narrative and story-telling inquiry. South African Journal of Human Resource Management, 10(2), 1-11. https://doi.org/10.4102/sajhrm.v10i2.447

Chinyamurindi, W. T. (2016a). Using narrative analysis to understand factors influencing career choice in a sample of distance learning students in South Africa. South African Journal of Psychology, 14(1), 1-11. https://doi. org/10.1177/0081246315623662

Chinyamurindi, W. T. (2016b). A narrative investigation on the motivation to become an entrepreneur among a sample of black entrepreneurs in South Africa: Implication for entrepreneurship career development education. Acta Commercii, 16(1), 1-9. https://doi.org/10.4102/ac.v16i1.310

Chinyamurindi, W. T., \& Louw, G. J. (2010). Gender differences in technology acceptance in selected South African companies: Implications for electronic
learning. South African Journal of Human Resource Management, 8(1), 1-7. https://doi.org/10.4102/sajhrm.v8i1.204

Chiwara, J. R., Chinyamurindi, W. T., \& Mjoli, T. Q. (2017). Factors that influence the use of the Internet for job-seeking purposes amongst a sample of final-year students in the Eastern Cape province of South Africa. South African Journal of Human in the Eastern Cape province of South Africa. South African Journal of Humd
Resource Management, 15, 1-9. https://doi.org/10.4102/sajhrm.v15i0.790

Creswell, J. W. (2009). Research design: Qualitative, quantitative, and mixed methods approaches (3rd edn.). London: Sage.

Creswell, J. W. (2014). Research design: Qualitative, quantitative, and mixed methods approaches (4th edn.). Thousand Oaks, CA: Sage.

Demers, E., \& Vega, C. (2010). Soft information in earnings announcements: News or noise? Working paper, France: INSEAD.

Diekmann, C., Blickle, G., Hafner, K., \& Peters, L. (2015). Trick or trait? The combined effects of employee impression management modesty and trait modesty on supervisor evaluations. Journal of Vocational Behaviour, 89, 120-129. https://doi. org/10.1016/j.jvb.2015.05.002

Dimba, B. A., \& Rugimbana, R. (2013). An assessment of the moderating role of employees' cultural orientations amongst foreign manufacturing multinational companies in Kenya. South African Journal of Human Resource Management, 11(1), 1-11. https://doi.org/10.4102/sajhrm.v11i1.453

Fisher, R., Schoenfeldt, J., \& Shaw, W. (2006). Human resource management (6th edn.). Boston, MA: Houghton Mifflin Company.

Fisk, R., \& Grove, S. J. (1996). Applications of impression management and the drama metaphor in marketing: An introduction. European Journal of Marketing, 30(9), 6-12. https://doi.org/10.1108/03090569610130061

Galletta, A., \& Cross, W. E. (2013). Mastering the semi-structured interview and beyond: From research design to analysis and publication 9780814732939.001 .0001

Goffman, E. (1959). The presentation of self in everyday life. Garden City, NY Doubleday Anchor.

Godfrey, J., Mather, P. \& Ramsay, A. (2003). Earnings and impression management in financial reports: The case of CEO changes. Abacus, 39(1), 95-123. https://doi. org/10.1111/1467-6281.00122

Grobler, P. A., Warnich, S., Carrell, M. R., Elbert, N. F., \& Hatfield, R. D. (2011). Human resource management. (4th edn.). London, UK: Cengage Learning EMEA.

Harry, T. T., Dodd, N. M., \& Chinyamurindi, W. T. (2017). Using narratives to understand the motivational factors and experience of being a self-initiated academic expatriate in South Africa. South African Journal of Human Resource Management, 15, 1-9. https://doi.org/10.4102/sajhrm.v15i0.797

Hooghiemstra, R. (2000). Corporate communication and impression management New perspectives why companies engage in corporate social reporting. Journal of Business Ethics, 27, 55-68. https://doi.org/10.1023/A:1006400707757

Howle, T. C., Jackson, B., Conroy, D. E., \& Dimmock, J. A. (2015). Winning friends and influencing people: Self-presentation motives in physical activity settings. International Review of Sport and Exercise Psychology, 8(1), 44-70. https://doi.or International Review of Sport and Exer
$\mathrm{g} / 10.1080 / 1750984 \mathrm{X} .2014 .991346$

Johnson, G., Griffith, J. A., \& Buckley, M. (2016). A new model of impression management: Emotions in the 'black box' of organizational persuasion. Journal of Occupational and Organizational Psychology, 89(1), 111-140. https://doi. of Occupational and Organ

Jones, E. E., \& Pittman, T. S. (1982). Toward a general theory of strategic selfpresentation. In J. Suls (Ed.), Psychological perspectives on the self (pp. 231-262) Hillsdale, NJ: Erlbaum. PMid:7043883

Kacmar, M., \& Carlson, D. (1999). Effectiveness of impression management tactics across human resource situations. Journal of Applied Social Psychology, 26(6) 1293-1315. https://doi.org/10.1111/j.1559-1816.1999.tb02040.x
Kerr-Phillips., B., \& Thomas, A. (2009). Macro and micro challenges for talent retention in South Africa. South African Journal of Human Resource Management, $7(1)$ 1-10. https://doi.org/10.4102/sajhrm.v7i1.157

Klapproth, D. M. (2004). Narrative as social practice: Anglo-Western and Australian aboriginal oral tradition. Berlin: Mouton de Gruyter. https://doi. org/10.1515/9783110197426

Kolb, D. M. (2017). Onstage with labor mediators: Some tactics of impression management (Classic Reprint). London: Fb \&C Limited.

Labov, W. (1972). Language in the Inner City: Studies in the Black English Vernacular. Philadelphia, PA: University of Pennsylvania Press.

Leary, M. R., \& Kowalski, R. M. (1990). Impression management: A literature review and two-component model. Psychological Bulletin, 107(1), 34-47. https://doi. org/10.1037/0033-2909.107.1.34

Leung, S., Parker, L., \& Courtis, J. (2015). Impression management through minimal narrative disclosure in annual reports. The British Accounting Review, 47(3), 275289. https://doi.org/10.1016/j.bar.2015.04.002

Louw, G. J. (2013). Exploring recruitment and selection trends in the Eastern Cape. South African Journal of Human Resource, 11(1), 1-10. https://doi.org/10.4102/ sajhrm.v11i1.319

Louw, J. (2012). Programme evaluation: Can it improve human resource management practice? South African Journal of Human Resource Management, 10(3), 1-5. https://doi.org/10.4102/sajhrm.v10i3.428

Manusov, V., \& Spitzberg, B. H. (2008). Attributes of attribution theory: Finding good cause in the search for theory. In D. O. Braithwaite \& L. A. Baxter (Eds.), Engaging theories in interpersonal (pp. 37-49). Thousand Oaks, CA: Sage.

McCormack, C. (2000). From interview transcript to interpretative story: Part 1. Viewing the transcript through multiple lenses. Field Methods, 12(4) 282-297. https://doi.org/10.1177/1525822X0001200402; https://doi.org/ 10.1177/1525822X0001200403

Merkl-Davies, D., Brennan, N. \& Mcleay, S. J. (2011). Impression management and retrospective sense-making in corporate narratives: A social psychology perspective. Accounting, Auditing \& Accountability Journal, 24, 315-344. https:// doi.org/10.1108/09513571111124036

Mtshelwane, D., Nel, J. A., \& Brink, L. (2016). Impression management within the Zulu culture: Exploring tactics in the work context. South African Journal of Industria Psychology, 42(1), 1-13. https://doi.org/10.4102/sajip.v42i1.1325

O'Neil, S. M., \& Horne, A. L. (2012). Evaluating the internalisation of core values at a South African public service organisation. South African Journal of Human Resource Management, 10(1), 1-14. https://doi.org/10.4102/sajhrm.v10i1.371

Patel, C. J., Gali, V. S., Patel, D. V., \& Parmar, R. D. (2011). The effects of information and communication technologies (ICTs) on higher education: From objectivism to social constructivism. International Journal of Vocational and Technical Education, 3(5), 113-120.

Ployhart, R. E., Schneider, B., \& Schmitt, N. (2006). Staffing organisation: Contemporary practice and theory (3rd edn.). NJ: Lawrence Erlbaum Associates.

Raghuram, S. (2013). Identities on call: Impact of impression management on Indian call centre agents. Human Relations, 66(11), 1471-1496. https://doi. org/10.1177/0018726713481069

Schlenker, B. R. (1980). Impression management: The self-concept, social identity, and interpersonal relations. Monterey, CA: Brooks/Cole.

Seiter, J. S., \& Gass, R. H (Eds.). (2004). Perspectives on persuasion, social influence, and compliance gaining. Boston, MA: Pearson/Allyn \& Bacon. PMCid:PMC1770287

Spitzberg, B. H., \& Manusov, V. (2014). Attributes of attribution theory: Finding good cause in the search for theory. In D. O. Braithwaite \& P. Schrodt (Eds.), Engaging theories in interpersonal communication ( 2 nd edn., pp. 37-50). Thousand Oaks, CA: Sage.

Stiff, J. P. (1996). Theoretical approaches to the study of deceptive communication: Comments on interpersonal deception theory. Communication Theory, 6(3), 289-296. https://doi.org/10.1111/j.1468-2885.1996.tb00130.x

Sung, C., Lin, C.-C., Connor, A., \& Chan, F. (2017). Disclose or not? Effect of impression management tactics on hireability of persons with epilepsy. Epilepsia, 58(1), 128-136. https://doi.org/10.1111/epi.13619; PMid:27869304

Tsai, W., \& Huang, T. (2014). Impression management during recruitment process. In K. Y. T. Yu \& D. M. Cable (Eds.), The Oxford handbook of recruitment (pp. 314-334) New York: Oxford University Press.

Ward, A. K., \& Ravlin, E. C. (2016). Building influence as an outsider: A theoretical approach to cross-cultural impression management. Human Resource Management Review, 27(3), 491-506. https://doi.org/10.1016/j.hrmr.2016.12.013

Wilhelmy, A., Kleinmann, M., Konig, C. J., Melchers, K. G., \& Truxillo, D. M. (2015). How and why do interviewers try to make impressions on applicants? A qualitative study. Journal of Applied Psychology, 101(3), 313-332. https://doi.org/10.1037/ apl0000046; PMid:26436440

Yan, L. \& Ho, H. (2017). Impression management of tour leaders. Asia Pacific Journal of Tourism Research, 22(4), 422-435. https://doi.org/10.1080/109416 Journal of Tourism
65.2016 .1276086

Yu, K. Y. T., \& Cable, D. M. (Eds.). (2014). The Oxford handbook of recruitment. New York: Oxford University Press.

Zhao, M., \& Liden, R. L. (2011). Internship: A recruitment and selection perspective. Journal of Applied Psychology, 96(1), 221-229. https://doi.org/10.1037/ a0021295; PMid:20954757 